\title{
Efektifitas Mobile Apps pada Metode Mindmap untuk Meningkatkan Hasil Belajar dan Mengurangi Penyalahgunaan Smartphone
}

\author{
Tejo Nurseto, Ahmad Chafid Alwi, \& Kiromim Baroroh \\ Universitas Negeri Yogyakarta, Indonesia \\ tejo@uny.ac.id,ahmadchafidalwi@uny.ac.id,kiromim_b@uny.ac.id
}

\begin{abstract}
Abstrak: Penelitian ini memiliki tujuan untuk mengetahui efektivitas penggunaan mobile app dalam meningkatkan hasil belajar mahasiswa dan mengurangi penyalahgunaan penggunaan smartphone saat pembelajaran. Penelitian ini merupakan quasi experimental design dengan model non-equivalent group pretest posttest yang diterapkan pada kelas eksperimen dan kelas kontrol. Analisis data dalam penelitian ini menggunakan uji t. Hasil penelitian menunjukkan bahwa penggunaan mobile apps pada metode Mindmap cukup efektif untuk meningkatkan prestasi belajar dan mampu mengurangi kebiasaan mahasiswa dalam penyalahgunaan penggunaan smartphone.
\end{abstract}

Kata kunci: Hasil Belajar, Penyalahgunaan Smartphone, Mobile Apps, Metode Mindmap

\section{The Effectiveness Of Mobile Apps On The Mindmap Method To Improve Learning Outcomes And Reduce Smartphone Abuse}

\begin{abstract}
This study aims to determine the effectiveness of using mobile apps in improving student learning outcomes and reducing abuse of smartphone use during learning. This research is a quasi-experimental design with a non-equivalent group pretestposttest model applied to the experimental class and the control class. Data analysis in this study using the t-test. The results showed that the use of mobile apps in the Mindmap method was competent enough to improve learning achievement and was able to reduce student habits in the abuse of smartphone use.
\end{abstract}

Keywords: Learning Outcomes, Smartphone Abuse, Mobile Apps, Mindmap Methods

\section{PENDAHULUAN}

Isu tentang aturan boleh-tidaknya siswa membawa smartphone selama pembelajaran masih terus menjadi perdebatan. Meski saat ini Pemerintah menyerahkan kebijakan ini sepenuhnya kepada pihak sekolah, masih terdapat berbagai perbedaan dalam penerapannya. Ada sekolah yang memperbolehkan siswanya membawa smartphone selama pembelajaran dengan alasan dapat membantu menambah referensi, namun juga tidak sedikit sekolah yang melarang dengan alasan akan mengganggu proses pembelajaran. Nampaknya disrupsi yang terjadi dalam revolusi industri 4.0 membawa pergeseran yang cukup signifikan dalam pembelajaran. Smartphone juga menjadi benda yang paling dekat dengan semua orang termasuk siswa. Bahkan tidak sedikit siswa di mana instansinya sudah melarang membawa smartphone tetapi mereka masih secara sembunyi-sembunyi membawa smartphone ke dalam kelas dan bahkan menggunakannya secara sembunyi-sembunyi selama proses pembelajaran.

Beberapa studi menunjukkan gambaran penggunaan smartphone ketika proses pembelajaran diantaranya dilakukan oleh (Gusti Yarmi, I. L. 2017: 55), dalam penelitiannya selama tiga bulan yang melibatkan 64 mahasiswa menunjukkan pemanfaatan handphone untuk digunakan dalam proses belajar masih minim dan masih banyaknya aplikasi media sosial yang sering dibuka oleh mahasiswa. Studi lain yang dilakukan oleh (Hasan Jamani, 2013: 2), Hasil penelitian menunjukkan bahwa, masih ada siswa yang menggunakan handphone di sekolah baik di dalam kelas maupun di luar kelas, akibatnya dapat mengganggu proses belajar mengajar dan tidak mencapai ketuntasan dalam mengikuti pelajaran walaupun peraturan mengenai larangan 
membawa dan menggunakan Handphone di sekolah sudah disosialisasikan namun masih ada siswa yang melanggar.

Banyak pelajar yang menghabiskan waktunya untuk membalas pesan WhatsApp, melihat status, dan mengupdate status (Hashim et al., 2015: 97). Bahkan juga mempengaruhi konsentrasi mereka saat belajar. Tidak sedikit pula remaja dengan smartphonenya menunjukkan defek moral saat pembelajaran dan menggunakan sosial media.

Penelitian yang telah dilakukan di atas masih belum menunjukkan adanya solusi praktis yang dapat berdampak pada hasil belajar siswa. Pada studi yang dilakukan berbentuk penelitian survey dan menunjukkan gambaran penggunaan smartphone dikalangan mahasiswa dan hanya merekomendasikan untuk menggunakan moodle (Gusti Yarmi, 2017: 55). Sebuah penelitian deskriptif juga masih belum memberikan solusi (Hasan Jamani, 2013: 2). Tampak pada penelitian tersebut peraturan yang diterapkan oleh sekolah hanya bersifat mengekang (larangan dan sanksi). Sehingga masih ditemukan beberapa anak yang melanggar aturan tersebut seperti sering mengirim pesar saat proses pembelajaran berlangsung, berkawan hanya pada teman yang memiliki handphone (hampir sevarian), mengambil dan mengirim gambar temannya saat berada di toilet, siswa menjadi individualistik, sering berpindah tempat duduk untuk melihat handphone teman, dan bahkan ada temuan tindakan kriminal. Hal ini juga terjadi pada mahasiswa pendidikan ekonomi FE-UNY, dimana hasil wawancara awal menunjukkan bahwa mereka memang sebagian besar menggunakan smartphone saat perkuliahan, diantara mereka ada yang menggunakannya untuk untuk membalas pesan Whatsapp, update status di Facebook, Twitter, atau Instagram. Disinilah duduk masalah sebenarnya yang cukup penting yang harus segera diselesaikan. Jika dilihat dari skema masuknya informasi kedalam memori, maka memungkinkan akan terjadi gangguan masuknya informasi ke dalam memori.

Hal ini ternyata juga terjadi pada mahasiswa pendidikan ekonomi, ketika melakukan wawancara awal dengan pertanyaan "Apa yang kalian rasakan ketika ditengah penjelasan dosen ada pesan dari Whatsapp atau postingan teman kalian di sosmed kemudian kalian membalas pesan mereka atau memberikan komentar atas status mereka? Lalu kemudian apakah setelah itu kalian bisa langsung melanjutkan memahami penjelasan dosen?". Sebagian besar dari mereka menjawab cukup susah langsung turn in dengan penjelasan dosen. Saat mahasiswa menerima penjelasan maka ada stimulus yang masuk dan kemudian saat mereka membuka pesan atau status orang dalam sosmed maka ada stimulus lain yang masuk sehingga mereka susah berkonsentrasi untuk memastikan stimulus masuk pada memori jangka pendek dan ini bisa dimasukkan kedalam memory-slip (Hay \& Jacoby, 1996: 1323).

Penelitian ini akan sangat berguna bagi semua pendidik, baik dosen maupun guru dalam pembelajarannya di kelas sehingga masalah yang lazim terjadi di kelas seperti penyalahgunaan penggunaan smartphone dapat diminimalisir dan bahkan dapat meningkatkan efektifitas dari fungsi smartphone dalam pembelajaran. Sudah tidak dapat dielakkan lagi bahwa teknologi akan selalu dekat dengan siswa (manusia). Maka yang diperlukan adalah sebuah solusi yang dapat mengurangi penyalahgunaan penggunaan smartphone selama proses pembelajaran berlangsung, yakni dengan teknik Aplikasi mobile app. Sehingga, penyalahgunaan dapat diminimalisir dan diharapkan hasil belajar dapat meningkat karena sumber referensi juga semakin kaya. Teknik ini membawa konsep penggunaan device (smartphone) selama proses pembelajaran berlangsung sebagai sumber mencari referensi, tempat mengerjakan tugas, membuat presentasi, mengirim hasil kerja dan kemudian untuk alat menjawab evaluasi.

Penggunaan teknologi dalam bentuk aplikasi pada smartphone dapat berfungsi sebagai teknik pembelajaran terbukti efektif untuk mencapai hasil pembelajaran (Abugohar et al., 2019: 74). 
Berdasarkan teori tersebut, penerapan teknik dengan mobile apps untuk memperlancar metode pembelajaran dalam mencapai tujuan pembelajaran maka dapat dibantu oleh teknologi yang berposisi sebagai media diskusi kelompok, pendukung blended-learning, dan media penyimpanan bersama dari hasil diskusi (Barhoumi, 2015: 221; Robles et al., 2019: 231; Sari et al., 2015: 28).

Penggunaan metode dan media yang sesuai akan berdampak pada hasil belajar siswa (Sutrisno \& Siswanto, 2016). Hasil belajar merupakan kemampuan perubahan perilaku seseorang yang diperoleh setelah mengikuti proses belajar, sedangkan prestasi belajar umumnya berkenaan dengan aspek pengetahuan (Arifin, 2009:12).

\section{METODE}

Penelitian ini bertujuan untuk mengetahui peningkatan pada pemahaman konsep dan pengurangan pada penyalahgunaan penggunaan smartphone. Untuk mencapai tujuan tersebut penelitian ini menggunakan jenis Quasi experimental design dengan desain Non-equivalent Group Pretest Postest Design. Jenis eskperimen pada penelitian ini adalah nonequivalent control group design. Dimana kelas kontrol dengan jumlah mahasiswa 10 orang dan kelas eksperimen juga berjumlah 10 orang tidak dipilih secara random. Sebagai upaya membuat situasi penelitian mendekati kondisi eksperimen laboratorium, kelas dibagi atas hasil tes yang sebelumnya sudah dilakukan oleh dosen praktikan (Kerlinger, 1986: 646). Selanjutnya dilakukan uji homogenitas untuk memastikan kemampuan mereka tidak jauh berbeda. Kemudian diberikan pretest untuk mengetahui keadaan awal dan posttest setelah diberi perlakuan.

Data yang dikumpulkan kemudian dianalisis dengan metode kuantitatif. Metode kuantitatif dilaksanakan setelah pelaksanaan perlakuan, Sebelum dilakukan uji independent test, telah dilakukan uji homogenitas, normalitas, dan paired test. Hasil dari analisis data kedua metode dijadikan dasar untuk menginterpretasi data yang diperoleh.

\section{HASIL DAN PEMBAHASAN}

Pembelajaran diawali dengan pengunggahan referensi dari guru kedalam google drive. Kemudian dilanjutkan dengan proses pembelajaran menggunakan metode mindmap, mahasiswa mengikuti apersepsi dosen. Pendekatan dalam pembelajaran adalah discovery learning. Dalam proses pencarian sumber belajar, mahasiswa menggunakan referensi yang sudah diunggah di drive dan source engine. Mahasiswa menggunakan aplikasi miMind dalam membuat konsep atas pemahaman yang mereka peroleh dari berbagai referensi. Kemudian mahasiswa mengunggah dokumen pada drive bersama dan melakukan presentasi. Secara skematik proses pembelajaran dapat digambarkan dalam began berikut:

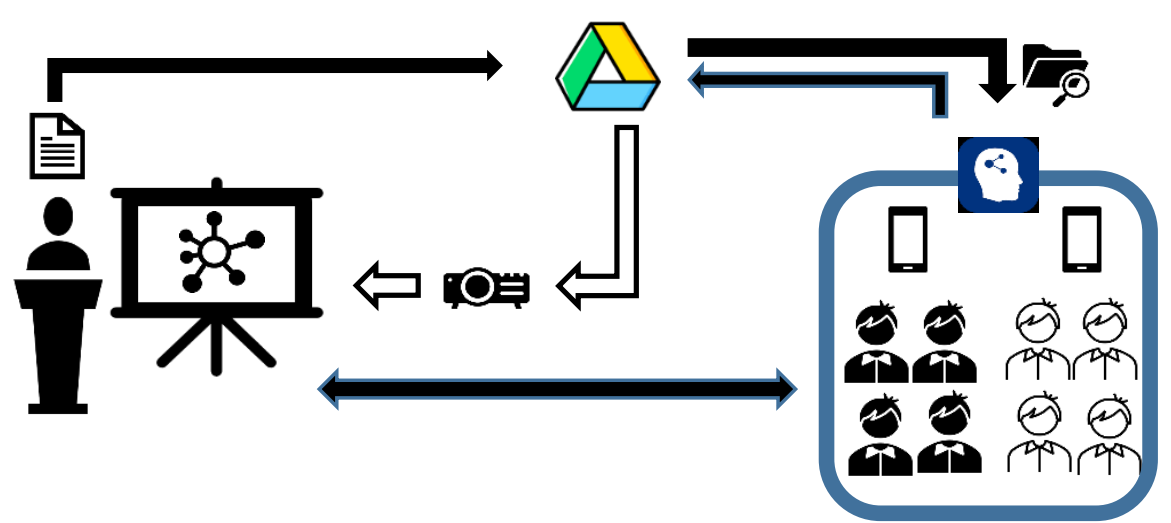

Gambar 1. Skema pembelajaran menggunakan aplikasi mobile app dalam metode mindmap 
Dalam pelaksanaannya harus dipastikan mahasiswa juga memiliki akun matakuliah yang sudah dibuat oleh dosen. Sehingga dalam hal ini mahasiswa dan dosen memiliki akun bersama baik email dan akun google drive yang digunakan untuk menyimpan hasil kerja.

Berdasarkan eksperimen yang sudah dilaksanakan dilakukan pengambilan data melalui beberapa pengujian, pemberian angket dan wawancara dengan hasil sebagai berikut:

Tabel 1. Hasil Uji Normalitas

\begin{tabular}{ccccc}
\hline & Kelas & Kolmogrov-Smirnov & Sig. \\
\cline { 3 - 5 } Hasil Belajar & $\begin{array}{c}\text { Pre-test kelas } \\
\text { eksperimen }\end{array}$ & .293 & 10 & .015 \\
$\begin{array}{c}\text { Post-test kelas } \\
\text { eksperimen } \\
\text { Pre-test kelas } \\
\text { control }\end{array}$ & .174 & 10 & $.200^{*}$ \\
& $\begin{array}{c}\text { Pre-test kelas } \\
\text { kontrol }\end{array}$ & .236 & 10 & .123 \\
\hline
\end{tabular}

Uji tersebut menunjukkan bahwa tes yang dilakukan di kedua kelas berdistribusi normal, yang kemudian akan dapat dilanjutkan ke uji paired sample t-Test. Sebelum menguji perbandingan kelas control dan kelas eksperimen, uji paired sample t test menunjukkan hasil perbandingan pretest dan posttest pada setiap kelas. Hasil paired sample t-test tampak pada tabel 2.

Tabel 2 Paired Sample Test

\begin{tabular}{ccc}
\hline & & Sig. (2-tailed) \\
\hline Pair 1 & $\begin{array}{c}\text { Pre test kelas eksperimen - } \\
\text { posttest kelas eksperimen }\end{array}$ & .000 \\
Pair 2 & $\begin{array}{c}\text { Pre test kelas control - post } \\
\text { test kelas kontrol }\end{array}$ & .001 \\
\hline
\end{tabular}

Pada sample t-test ini signifikansi berada di bawah 0.05 maka menunjukkan adanya perbedaan hasil belajar pada pre-test dan pos-test pada kelas eksperimen.

Hal ini di dukung oleh hasil penelitian yang menunjukkan bahwa mahasiswa memiliki kemudahan dan kecepatan dalam mengakses materi yang terhimpun dalam google drive melalui smartphone (Warsito \& Yuliandini, 2017). Mahasiswa memiliki akses pada sumber belajar yang digunakan di kelas bisa kapan saja dan dimana saja, baik menggunakan smartphone maupun menggunakan device lain seperti laptop. Hal ini berbeda dengan kelas control yang tidak menggunakan google drive dan media grup Whatsapp. Meskipun tidak menjadi sebuah keharusan, uji homogenitas tetap dilakukan sebelum melakukan uji independent t-test. Pada uji homogenitas disajikan pada tabel 3 .

$\underline{T a b e l} 3$ hasil uji homogenitas

\begin{tabular}{lcl}
\hline & & Sig \\
\hline Hasil belajar & Based on Mean & .693 \\
Mahasiswa & Based on Median & .749 \\
& Based on Median and with adjusted df & .749 \\
& Based on trimmed mean & .711 \\
\hline
\end{tabular}


Berdasarkan output diatas, diketahui bahwa nilai signifikansi based on mean lebih besar dari 0.05 sehingga dapat disumpulkan bahwa varian data pada post test kelas eksperimen dan posttest kelas kontrol adalah homogen sehingga kedua kelas tersebut layak untuk menjadi kelas penelitian.

$\underline{\text { Tabel } 4 \text { Independent sample Test }}$

\begin{tabular}{ccc}
\hline & & Sig (2-tailed) \\
\hline Hasil Belajar & Equal variance assumed & .043 \\
& Equal variances not assumed & .043 \\
\hline
\end{tabular}

Karena data homogen, maka berdasarkan data equal variances assumed adalah 0.043 dan berada di bawah 0.05, maka dapat disimpulkan bahwa ada perbedaan rata-rata hasil belajar mahasiswa antara menggunakan teknik pembelajaran dengan aplikasi android dalam penerapan Mind Map, sehingga hipotesis diterima.

Tabel 5 Data deskriptif setelah Independen Test

\begin{tabular}{cccccc}
\hline Kelas & N & Mean & $\begin{array}{c}\text { Std. } \\
\text { Deviation }\end{array}$ & $\begin{array}{c}\text { Std. Eror } \\
\text { mean }\end{array}$ \\
\hline Hasil Belajar & Postest kelas Eksperimen & 10 & 81.00 & 11.972 & 3.786 \\
& Postest Kelas Kontrol & 10 & 70.00 & 10.541 & 3.33 \\
\hline
\end{tabular}

Berdasarkan hasil pada tabel 4.5, maka dapat dilanjutkan untuk melihat Gain Score agar dapat dilihat kategori efektivitas perlakuan. Tabel deskripsi Gain Score disajikan pada tabel 4.7.

Tabel 6 Data N Gain Score

\begin{tabular}{ccc}
\hline & Kelas & Statistic \\
\hline \multirow{2}{*}{$\mathrm{N}$ gain } & Kelas Eksperimen & 69.4 \\
& Kelas Kontrol & 42.0 \\
\hline
\end{tabular}

Berdasarkan kriteria N-Gain dari (Hake, 1999) pada tabel 6 maka pembelajaran dengan aplikasi mobile app yang digunakan pada metode pembelajaran mindmapping masuk dalam kategori cukup efektif (69\%). Hal ini bisa jadi disebabkan oleh kemudahan mobile apps dalam membantu metode pembelajaran Mind Map. Mahasiswa dapat membuat mindmap dengan lebih praktis menggunakan aplikasi MiMind, kemudian melihat referensi dari google drive, serta hasil kerja yang bisa lihat bersama oleh setiap mahasiswa karena telah diunggah di Google Drive. Dalam hal ini Google drive memiliki kelebihan dalam efektivitas system informasi (Ningrum, 2015: 11). Bahkan pernyataan dari dosen pengajar setelah dilakukan wawancara menyatakan bahwa dengan demikian hasil kerja dan berbagai referensi tidak akan takut hilang apalagi jika hanya dicetak atau disimpan dalam flashdisk sering ketinggalan, sehingga susah jika ingin membuka kembali.

Hasil ini didukung oleh hasil penelitian (Barhoumi, 2015: 232) dimana pada studi experimentasinya menunjukkan bahwa penggunaan Whatsapp dalam mobile learning dapat mempermudah siswa dalam berdiskusi dan berkolaborasi. Hal ini juga senada dengan hasil penelitian dari (Chear, 2017: 87) yang menyebutkan bahwa mobile learning yang difasilitasi oleh Whatsapp dapat membuat mahasiswa lebih memahami hasil pembelajaran. Pada penelitian lain, melalui sebuah penelitian dengan model Technology Continuance Theory menunjukkan hasil yang positif jika mahasiswa menggunakan teknologi google drive, di mana mahasiswa memiliki kepuasan dan akan berlanjut pada intensitas penggunaan yang tinggi kedepannya (Erawan \& Pambudi, 2017: 191). 
Berdasarkan hasil pada observasi awal sebelum diberikan perlakuan berupa penggunaan mobile apps pada metode mindmap yang dilakukan dengan cara memberikan angket pada mahasiswa kelas eksperimen menunjukkan bahwa 90 \% mahasiswa menggunakan social media dengan rincian $60 \%$ mahasiswa memiliki kebiasaan membaca status WA/instagram/facebook teman mereka, bahkan 30\% sering membuka social media dan kadang juga update status, meski mereka sedang berada dalam pembelajaran di kelas. Hal ini dikonfirmasi melalui hasil reduksi wawancara yang menunjukkan bahwa beberapa dari responden yang biasa beberapa kali menggunakan smartphone untuk social media saat perlakuan diterapkan mereka tidak lagi ada kesempatan menggunakan smartphone untuk aktvitas diluar pembelajaran.

Kemudian terkait dengan kebiasaan responden saat pembelajaran menunjukkan $70 \%$ jarang dan 30\% sering dari mereka menunggu pesan masuk melalui WA/Instagram/FB saat pembelajaran berlangsung. Terdapat 20\% berinteraksi rata-rata tiga kali dan $40 \%$ rata-rata 2 kali berinteraksi dengan media sosial. Hal ini menunjukkan adanya fokus yang terbagi dari mahasiswa saat mengikuti perkuliahan. Hal-hal seperti ini yang kemudian akan mengganggu proses masuknya informasi dari sensory memory kedalam memori jangka pendek mahasiswa (Marzano, 1998). Setelah diberikan perlakuan ternyata mahasiswa juga masih mengharap adanya pesan masuk. Hal ini mungkin terjadi karena sebelum perkuliahan responden melakukan komunikasi dengan media social dan tertunda komunikasinya karena perkuliahan sudah dimulai.

Sekitar 60\% mahasiswa sebelum diberikan perlakuan sering menggunakan kamera saat pembelajaran. Setelah dikonfirmasi saat wawancara, kamera digunakan untuk selfie dan beberapa dari mereka menggunakan untuk memfoto materi yang bisasanya ditampilkan oleh dosen saat presentasi. Adakalanya hasil foto tersebut juga kurang jelas karena kondisi ruangan dan pixel kamera yang tidak terlalu tinggi (di bawah 13 pixel). Setelah diberikan perlakuan dengan teknil mobile apps yang digunakan dalam metode pembelajaran Mind Mapping, kebiasaan mahasiswa berubah dengan tidak lagi menggunakan kamera saat pembelajaran. Mereka merasa terbantu dengan adanya materi yang dibagi melalui grup Whatsapp dan diunggah dalam google drive. Mereka tidak lagi merasa khawatir tertinggal materi serta bisa diakses dimana saja dan kapan saja.

Berikutnya baik sebelum dan sesudah perlakuan ternyata sebagian besar mahasiswa masih merasa bosan dengan pembelajaran yang dilakukan oleh dosen praktikan. Hal ini ditunjukkan dari hasil $60 \%$ sebelum perlakuan dan bertambah menjadi $70 \%$ saat setelah perlakuan mahasiswa memiliki rasa bosan dengan pembelajaran dan memiliki keinginan untuk membuka game pada smartphone. Namun Hal ini memang menjadi factor eksternal dari penelitian yang memang perlu untuk diperbaiki. Informasi ini menjadi penting untuk diperhatikan demi memperbaiki penggunaan mobile apps sebagai Teknik pembelajaran.

\section{SIMPULAN}

Penggunaan aplikasi pada mobile apps yang diterapkan pada metode Mind Mapping cukup efektif untuk meningkatkan hasil belajar mahasiswa jurusan Pendidikan ekonomi pada matakuliah ekonomi Pendidikan. Penggunaan aplikasi pada mobile apps mampu mengurangi kebiasaan mahasiswa dalam penyalahgunaan penggunaan smartphone saat pembelajaran berlangsung, misallnya tidak lagi menggunakan media sosial dan kamera diluar konteks pembelajaran. 


\section{DAFTAR PUSTAKA}

Abugohar, M. A., Yunus, K., \& Rashid, R. A. (2019). Smartphone applications as a teaching technique for enhancing tertiary learners' speaking skills: Perceptions and practices. International Journal of Emerging Technologies in Learning, 14(09), 74-92.

Arifin, Z. (2009). Evaluasi Pembelajaran. Bandung: PT Remaja Rosdakarya.

Barhoumi, C. (2015). The Effectiveness of WhatsApp Mobile Learning Activities Guided by Activty Theory on Students' Knowldege Management. Contemporary Educational Technology, 6(03), 221-238.

Chear, S. L. S. (2017). Jurnal Pendidikan Malaysian Journal Of Education. Jurnal Pendidikan Malaysia, 42(2), 87-97.

Erawan, Y., \& Pambudi, R. (2017). Analisis Penerimaan Dan Penggunaan Teknologi Google Drive Secara Berkelanjutan Pada Mahasiswa Fakultas Ekonomi Dan Bisnis Unika Atma Jaya Jakarta. Jurnal Akuntansi, 10(2), 191-205.

Gusti Yarmi, I. L. (2017). Pemanfaatan Handphone di Kalangan Mahasiswa. Perspektif Ilmu Pendidikan, 31(1), 55-59.

Hake, R.R. (1999). Analizing Change/ Gain Scores. [Online]. Tersedia: http://www.physics.indiana.edu/ sdi/AnalyzingChange-Gain.pdf

Hasan Jamani. (2013). Perilaku Siswa Pengguna Handphone Studi Kasus pada Siswa SMP Negeri 4 Sungai Raya Kabupaten Kubu Raya. Jurnal Program Magister Ilmu Sosial Universitas Tanjungpura, 1(0001), 1-14.

Hashim, N. A., Abdullah, N. L., Isa, R. M., \& Janor, H. (2015). WhatsApp Messenger Application among Business Students In Malaysia - An Exploration. Jurnal Personalia Pelajar, 18(2), 97-105.

Hay, J. F., \& Jacoby, L. L. (1996). Separating habit and recollection: Memory slips, process dissociations, and probability matching. Journal of Experimental Psychology: Learning Memory and Cognition, 22(6), 1323-1335.

Kerlinger, F. (1986). Foundations of Behavioral Research 3rd Ed. In Foundations of behavioral research.

Marzano, R. (1998). A Theory-Based Meta-Analysis of Research on Instruction. Colorado: MidContinent Regional Educational Lab.

Ningrum, O. S. \& Durinta Puspasari. (2015). Penggunaan Aplikasi Google Drive Sebagai Penunjang Paperless Office. Ilmu Sosial, 1-15.

Robles, H., Guerrero, J., Llinás, H., \& Montero, P. (2019). Online Teacher-Students Interactions Using Whatsapp In A Law Course. Journal of Information Technology Education: Research, 18, 231-252.

Sari, K., Sumarjaya, I. W., \& Nilakusumawati, D. (2015). Perbandingan Model Pembelajaran Menggunakan Google Drive Dan Tanpa Google Drive. Prosiding Seminar Nasional Teknologi Informasi \& Aplikasinya. 28-34.

Sutrisno, V. L. P., \& Siswanto, B. T. (2016). Faktor-Faktor Yang Mempengaruhi Hasil Belajar Siswa Pada Pembelajaran Praktik Kelistrikan Otomotif Smk Di Kota Yogyakarta. Jurnal Pendidikan Vokasi, 6(1), 111-120.

Warsito, A. B., \& Yuliandini, E. (2017). Penerapan Google Drive Untuk Efisiensi Penyimpanan Bahan Ajar Yang Dapat Mendukung Sistem Informasi Bahan Ajar Pada Perguruan Tinggi Berbasis Mobile Aplikasi. SISFOTENIKA, 7(2), 219-228. 